\title{
PRODUCTION TECHNIQUES OF ARBOREAL SPECIES SEEDLINGS AND USE OF MULCHING IN AN ALTERED AREA
}

\author{
Thairini Claudino Zavistanovicz ${ }^{2 *} \odot$, Suelen Carpenedo $\mathrm{Aimi}^{3} \odot$, Maristela Machado Araujo $^{3} \odot$,

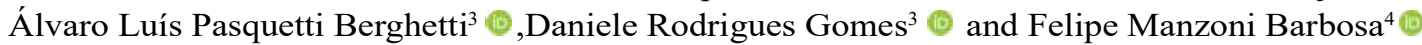

\footnotetext{
${ }^{1}$ Received on 15.02.2020 accepted for publication on 29.03.2021.

2 Secretaria de Estado da Infraestrutura e Mobilidade, Santa Catarina, SC - Brasil. E-mail: <thairini.z@gmail.com>.

${ }^{3}$ Universidade Federal de Santa Maria, Departamento de Ciências Florestais, Santa Maria, RS - Brasil. E-mail: <suaimi@gmail.com>, <araujo.maristela@gmail.com>,<alvaro.berghetti@gmail.com> and<eng.danielegomes@gmail.com>.

${ }^{4}$ Universidade Federal do Paraná, Programa de Pós-Graduação em Engenharia Florestal, Curitiba, PR - Brasil. E-mail: $<$ felipemanzonibarbosa@hotmail.com>.

*Corresponding author.
}

\begin{abstract}
Among the methods used for the restoration of altered areas, the planting of native tree seedlings is one of the most traditional ones. The objective of this study was to evaluate the survival and initial growth of Casearia sylvestris Sw, Handroanthus heptaphyllus Vell. Mattos and Parapiptadenia rigida Benth. Brenan seedlings in altered areas, according to containers used in nursery seedlings production and use of mulching on planting, using morphological and physiological attributes. The experiment was conducted in a $2 \times 2$ factorial scheme. The type of containers used (plastic bag and tube) was considered, and the presence or absence of mulching around the seedlings. The three species presented similar survival averages at 24 months. The rates between the treatments were $72.5 ; 85.0$ and $80.0 \%$, respectively. The use of plastic bags had a positive impact on the height (IncH) and stem collar (IncDC), crown area (CA) and shoot dry mass (SDM) for C. sylvestris and $H$. heptaphyllus, while for $P$. rigida, the use of plastic bags favored the CA and the SDM. The presence of mulching favored the attributes IncH, IncDC, AC, and MSPA of $H$. heptaphyllus, as well as CA and SDM of C. sylvestris. Regarding the physiological parameters (relative levels of chlorophyll $a$ and $b$ and fluorescence of chlorophyll a), no difference was observed between the treatments tested. It is recommended that for the planting of seedlings of $C$. sylvestris, $H$. heptaphyllus, and $P$. rigida, in altered areas by anthropization, they be produced in a $1.5 \mathrm{~L}$ plastic bag, aiming at greater field growth. Also, in the planting of C. sylvestris and $H$. heptaphyllus the mulching should be used to favor their growth.
\end{abstract}

Keywords: Plastic bag; Tubs; Morphological and physiological attributes.

\section{TÉCNICAS DE PRODUÇÃO DE MUDAS DE ESPÉCIES ARBÓREAS E USO DE MULCHING EM AREA ALTERADA}

RESUMO - Entre os métodos utilizados para a restauração de áreas alteradas, tem-se o plantio de mudas arbóreas nativas como um dos mais tradicionais. O objetivo desse estudo foi verificar a sobrevivência e o crescimento de mudas de Casearia sylvestris Sw, Handroanthus heptaphyllus Vell. Mattos e Parapiptadenia rigida Benth. Brenan, em área alterada, de acordo com o recipiente utilizado na produção das mudas em viveiro e do uso de mulching no plantio, por meio de atributos morfológicos e fisiológicos. O experimento foi conduzido em esquema fatorial 2x2, considerando tipos de recipientes na produção das mudas (saco plástico e tubete) e presença ou ausência de mulching no entorno das mudas no plantio. As três espécies apresentaram médias de sobrevivência semelhantes aos 24 meses. As taxas entre os tratamentos foram 72,5; 85,0 e 80,0\%, respectivamente. Obteve-se efeito positivo do uso de saco plástico para incremento em altura (IncH) e em diâmetro coleto (IncDC), área da copa (AC) e massa seca da parte aérea (MSPA) para $\boldsymbol{C}$. sylvestris $e \boldsymbol{H}$. heptaphyllus, enquanto para P. rigida, o uso do saco plástico favoreceu à AC e MSPA. A presença de mulching favoreceu os atributos IncH, IncDC, AC e MSPA de H. heptaphyllus, bem como a AC e a MSPA de C. sylvestris. Quanto aos parâmetros fisiológicos (níveis relativos de clorofila a e b e fluorescência de clorofila a), não foi observada diferença entre os tratamentos testados. Indica-se que mudas de $\boldsymbol{C}$. sylvestris, $\boldsymbol{H}$. heptaphyllus e $\boldsymbol{P}$. 
rigida, para plantio em área antropizada, sejam produzidas em recipiente saco plástico de 1,5 L visando maior crescimento a campo. Além disso, no plantio de C. sylvestris e H. heptaphyllus deve-se utilizar o mulching para favorecer seu crescimento.

Palavras-Chave: Saco plástico; Tubetes; Atributos morfológicos e fisiológicos.

\section{INTRODUCTION}

The intense demand for natural resources, together with the expansion of agriculture, livestock and urbanization, led to the deforestation of large forest areas in Brazil, resulting in the reduction of biodiversity and natural resources (Ferraz and Engel, 2011). There has been an increasing awareness of environmental conservation and sustainable management on a global scale. Nevertheless, many sites are still altered or degraded, requiring intervention, for restoring their environmental functionality.

In the last decade, the reforestation of altered areas by anthropogenic action has attracted the attention of public policies turned to the restoration of ecosystem services, aiming to recover the physiognomy of vegetation and its biological function (Paula et al., 2016). There are many methods for recovering altered areas, and choosing the most appropriate depends on the level of alteration of the environment, natural regeneration capacity, available financial resources, and other factors (Chazdon, 2008). Among the methods used for covering or recovering altered areas, the planting of native tree seedlings is one of the most traditional ones.

When seedlings with larger dimensions are chosen, in order to favor their survival and growth in the field, they are often produced in plastic bags. Nevertheless, it should be noted that the use of this container may have disadvantages, such as the demand for a high amount of substrate, long production cycles and the possibility of folding of the root system (Davide et al., 2015).

On the other hand, polypropylene tubes can be used, since they have internal splines in order to lead the root system, being able to improve the quality of the seedlings, besides facilitating the productive process (Gonçalves et al., 2005). However, they can restrict the growth of the plants because of their reduced size, thus causing deformations in the roots.
It is noteworthy that, although using seedlings produced with adequate inputs are used, the success of planting is also related to the management techniques adopted after this stage (Lima Filho et al., 2019; Brancalion et al., 2019), considering that the establishment of seedlings in the field is a critical phase for successful restoration (Campoe et al., 2014; Brancalion and Holl, 2020). Among the cultural treatments that may help the survival of the seedlings is the use of mulching after planting, aiming at reducing the surface temperature and the incidence of weeds, as well as maintaining moisture and reducing soil erosion (Silva et al.,2018).

In addition, it is still important to use the appropriate species, according to each site and purpose of planting. The species $C$. sylvestris, $H$. heptaphyllus and $P$. rigida, widely found in the south region, are among those recommended for use to cover altered areas. Although many studies have been carried out in order to evaluate factors that affect the development and establishment of tree species (Abreu et al., 2015; Zavistanovicz et al., 2020), these studies are usually not performed in altered environments.

Thus, it is important to know the morphological and physiological attributes of tree species, in order to predict their potential for use in restoration projects. This study aimed to evaluate the survival and initial growth of C. sylvestris, H. heptaphyllus and P. rigida seedlings in an altered area, according to the kind of container used in the production of seedlings and the use of mulching in the planting, through morphological and physiological attributes. It is believed that the highest survival rates, as well as greater growth of the seedlings and more adequate physiological attributes are verified in those produced in plastic bags, along with the use of mulching.

\section{MATERIAL AND METHODS}

The study was developed in the Parque Estadual Quarta Colônia (PEQC) (29²7'57,39's

Revista Árvore 2021;45:e4520 
and $53^{\circ} 16^{\prime} 51,30^{\prime \prime} \mathrm{O}$ ), a conservation unit of integral protection located in the state of Rio Grande do Sul, in the Atlantic Forest Biome. According to the Köppen climate classification, the climate of the region is classified as "Cfa", with well-distributed rains over the months ( $>40 \mathrm{~mm}$ per month), with the average temperature of the coldest month between -3 and 18 ${ }^{\circ} \mathrm{C}$ and the hottest month with temperatures higher than $22{ }^{\circ} \mathrm{C}$ (Alvares et al., 2013).

The PEQC area used for the experiment presents a history of anthropic intervention. This area is composed of small rural properties and a housing complex. After the evacuation of the area, the houses were demolished, but the debris was left behind and the soil was visibly compacted. Prior to the experiment, a vegetation composed basically of Brachiaria spp. (Brachiaria spp.), Andropogon bicornis L. (Burdock) and Eryngium horridum Malme (caraguata) was identified, in addition to some individuals of Pinus sp. and Eucalyptus sp.

\subsection{Production of seedlings}

The choice of tree species to compose the experiment was based on phytosociological studies carried out in the region. Those with rapid to moderate growth that could cover the area in the short term and which are commonly found in nurseries in the region were also chosen. Thus, three native species of the South region were selected: $C$. sylvestris, $H$. heptaphyllus and $P$. rigida.

The production of seedlings was carried out at the Forest Nursery of the Federal University of Santa Maria. Polypropylene conical tubes with $180 \mathrm{~cm}^{3}$ of volume were used in the production. The substrate used in the filling consisted of the mixture of a commercial substrate Carolina Soil ${ }^{\circledR}$ composed of Sphagnum peat (CS) and carbonated rice husk (CRH), in the ratio 4:1 $(\mathrm{v}: \mathrm{v})$, with base fertilization being carried out with controlled release fertilizer (Osmocote ${ }^{\circledR}$ 18-05-09 Mini Prill) at the dosage of $6 \mathrm{~g} \mathrm{~L}^{-1}$.

After 170 days of sowing, 50\% of the seedlings were transplanted to polyethylene plastic bags of 1,500 $\mathrm{cm}^{3}$ (18 cm height x $12 \mathrm{~cm}$ wide) filled with substrate composed of subsoil, CS and CRH (1:1:1). A different substrate composition for seedlings transplanted into plastic bags was used in view of the characteristics of that container (Abreu et al., 2015), where subsoil is generally used (Gonçalves et al., 2005). Subsequently,
Table 1 - Mean values of height $(\mathrm{H})$ and stem diameter (SD) of Casearia sylvestris, Handroanthus heptaphyllus and Parapiptadenia rigida seedlings at the time they were moved from nursery to planting.

Tabela 1 - Valores médios de altura $(H)$ e diâmetro do coleto (DC) de mudas de Casearia sylvestris, Handroanthus heptaphyllus e Parapiptadenia rigida no momento em que foram transferidas do viveiro para o plantio.

\begin{tabular}{lcccc}
\multicolumn{2}{c}{ H $(\mathrm{cm})$} & \multicolumn{3}{c}{ SD $(\mathrm{mm})$} \\
& Plastic bag & Tube & Plastic bag & Tube \\
\hline C. sylvestris & 25.0 & 22.0 & 4.76 & 4.07 \\
H. heptaphyllus & 26.7 & 17.2 & 8.03 & 5.21 \\
P. rigida & 55.8 & 42.7 & 7.02 & 6.49 \\
\hline
\end{tabular}

the seedlings remained in the nursery for eight months until planting in the field. In this period, top-dressings were applied to all the plants, with ammonium sulphate $\left(\left(\mathrm{NH}_{4}\right)_{2} \mathrm{SO}_{4}\right)$ and potassium chloride $(\mathrm{KCl})$, in accordance with the methodology of Gonçalves et al. (2005). At the time the seedlings were moved from the nursery to the field, they presented height (H) and stem diameter (SD) varying according to the container used (Table 1).

\subsection{Treatments and experimental design}

The experiment consisted of four treatments in a $2 \times 2$ factorial scheme, with the factor " $\mathrm{A}$ " being composed of two types of containers: seedlings produced in tubes and transplanted into polyethylene plastic bags, where they remained until planting and seedlings produced and kept in tubes until planting; and factor "B" composed of the presence and absence of mulching around seedlings in the planting. Each species was analyzed individually, according to the treatments, and the species was not a treatment factor.

The experiment was conducted in split plots, with the plot being composed of the container treatments used in the production, and in the subsplit plots the presence or absence of mulching, in a randomized block design. Each plot of $10.5 \mathrm{~m} \mathrm{x} 10 \mathrm{~m}$ consisted of a single species, with 35 individuals, according to the treatments, and space of $1.5 \mathrm{~m} \mathrm{x} 2.0 \mathrm{~m}$ between plants and $2 \mathrm{~m}$ between blocks, with a total of five blocks.

\subsection{Area preparation and planting}

Prior to planting, soil samplings were collected to characterize the area, with three samplings per block at depths of 0 to $20 \mathrm{~cm}$ and 20 to $40 \mathrm{~cm}$, using a cutting blade. The chemical analysis of the soil was performed by the Soil Analysis Laboratory of the

Revista Árvore 2021;45:e4520 
Table 2 - Chemical attributes of the soil of the planting area, in the Parque Estadual Quarta Colonia, RS.

Tabela 2 - Atributos químicos do solo da área de plantio, no Parque Estadual Quarta Colônia, RS.

\begin{tabular}{|c|c|c|c|c|c|c|c|c|c|c|c|c|}
\hline $\begin{array}{l}\begin{array}{l}\text { Soil } \\
\text { deep }\end{array} \\
(\mathrm{cm})\end{array}$ & $\begin{array}{c}\mathrm{pH} \\
\left(\mathrm{H}_{2} \mathrm{O}\right) \\
1: 1\end{array}$ & ----- & Clay & ---- & P-Mehlich & ------- & $\begin{array}{c}\mathrm{CEC} \\
\mathrm{pH} 7,0 \\
-\end{array}$ & $\mathrm{Ca}$ & $\mathrm{Mg}$ & Al & $\overline{\mathrm{H}+\mathrm{Al}}$ & $\begin{array}{l}\text { SMP } \\
\text { Index }\end{array}$ \\
\hline$\overline{0-20}$ & 5.90 & 0.94 & 14.8 & 83.3 & 32.8 & 130.4 & 12.9 & 7.5 & 2.9 & 0.0 & 2.1 & 6.6 \\
\hline $20-40$ & 5.88 & 0.94 & 17.4 & 84.0 & 38.7 & 134.4 & 13.7 & 8.4 & 2.8 & 0.0 & 2.2 & 6.6 \\
\hline
\end{tabular}

Being: OM - organic matter; $\mathrm{V}$ - base saturation; P-Mehlich - phosphorus extracted by the Mehlich method -1; K - potassium; $\mathrm{CEC} \mathrm{pH} \mathrm{7,0} \mathrm{-} \mathrm{cation} \mathrm{exchange} \mathrm{capaci-}$ ty; $\mathrm{Ca}$ - calcium; $\mathrm{Mg}$ - magnesium; $\mathrm{Al}$ - exchangeable aluminum and $\mathrm{H}+\mathrm{Al}$ - potential acidity.

Sendo: $M O$ - matéria orgânica; $V$ - saturação por bases; P-Mehlich - fósforo extraído pelo método Mehlich-1; K-potássio; CTC pH 7,0 - capacidade de troca de cátions; $\mathrm{Ca}$-cálcio; $\mathrm{Mg}$ - magnésio; $\mathrm{Al}$-aluminio trocável e $H+A l$-acidez potencial.

Federal University of Santa Maria (Table 2). Through the physical analysis of the soil, carried out at the Laboratory of Soil Physics of the UFSM, the textural class (pipette method) was determined, classifying it as sandy-loam.

Mechanized mowing was performed in the total area, followed by plot marking according to the treatments. Subsequently, pits with approximately $0.008 \mathrm{~m}^{3}(20 \mathrm{~cm} \times 20 \mathrm{~cm} \times 20 \mathrm{~cm})$ were opened with the use of a digger. After the area was prepared, seedlings were manually planted, in October 2013. It is noteworthy that, at the time of planting, both the seedlings from plastic bags and those from the tubes had a well-structured lump, with a large amount of roots added to the substrate, as well as thin and light roots.

After planting, the seedlings were irrigated, with about $2 \mathrm{~L}$ of water per plant. Then, the mulching was allocated around the seedlings that received this treatment. The mulching was obtained from dry grass (Brachiaria spp.), collected in the area adjacent to the experiment and allocated in a radius of approximately $20 \mathrm{~cm}$ and height of $5 \mathrm{~cm}$, around the stem of the plants. Replacements with the same material were done, every four months, during the first year of the experiment.

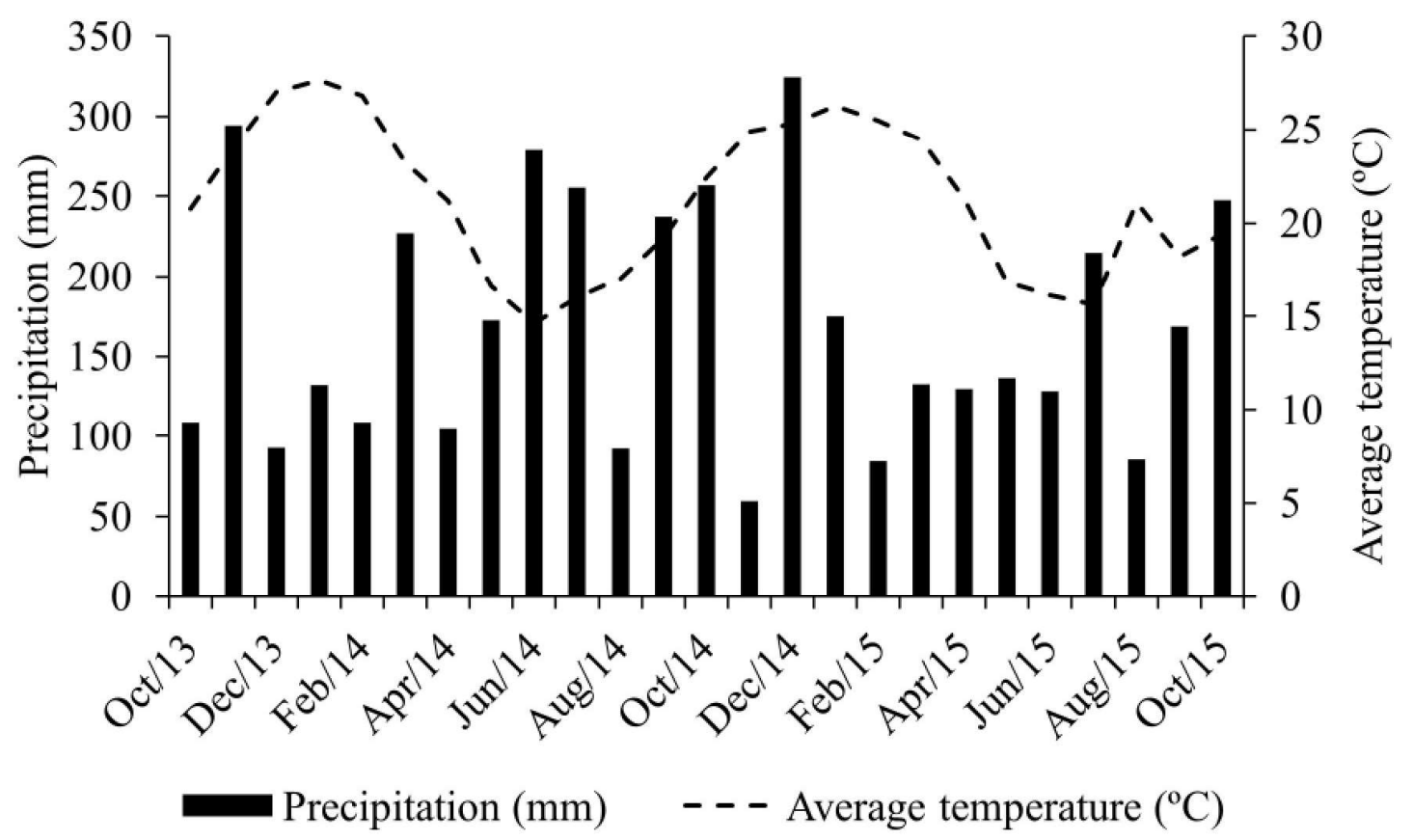

Figure 1 - Meteorological data of precipitation $(\mathrm{mm})$ and average temperature $\left({ }^{\circ} \mathrm{C}\right)$ registered in Santa Maria - RS, between October 2013 and October 2015 (www.inmet.gov.br/portal/).

Figura 1 - Dados meteorológicos de precipitação $(\mathrm{mm})$ e temperatura média $\left({ }^{\circ} \mathrm{C}\right)$ registrados em Santa Maria - RS, entre outubro de 2013 a outubro de 2015. (www.inmet.gov.br/portal)).

Revista Árvore 2021;45:e4520 
The replanting of the seedlings that did not survive was performed 60 days after the planting. In addition, the experiment was periodically monitored, with control of leafcutter ants through granulated baits (based on Fipronil and Sulfluramide) and weed control, performed by manual weeding around the seedlings (with subsequent replenishment of the mulching when it was dispersed), mowing in the crop rows and use of selective post-emergent herbicide (Sethoxydim $120 \mathrm{~g} / \mathrm{L}$ ) between the rows. $1.2 \mathrm{~L} /$ ha were applied with the aid of a backpack sprayer. The top-dressing in the experimental area was performed at 01, 12 and 24 months after planting, using Polyblen ${ }^{\circledR}$ controlled release fertilizer (N-P-K 18-08-18 + S + B).

The meteorological data of precipitation ( $\mathrm{mm}$ ) and average temperature $\left({ }^{\circ} \mathrm{C}\right)$, corresponding to the period of the experiment, were obtained from the National Meteorological Institute (INMET), located at the UFSM Campus, Santa Maria - RS (Figure 1).

\subsection{Evaluations of morphological and physiological attributes}

The survival of the seedlings was evaluated at 24 months after planting, through visual analysis. The height $(\mathrm{H})$, measured with a graduated ruler, and the stem diameter (SD), measured with a digital caliper, were measured at planting time and at 24 months of age, when the plants crown diameter was also measured (CrownD), with two horizontal perpendicular measurements (CrownD1 and CrownD2), with the aid of a graduated ruler, for later calculation of the crown area $(\mathrm{CA})$, where $\mathrm{CA}=$ $[(\text { CrownD } 1+\text { CrownD2 }) / 4]^{2 *} \pi$. For the morphological attributes described, the six central plants of each subplot were measured. The evaluation of the shoot dry mass (SDM), at 24 months of age, was determined by sectioning one plant per replicate (representative of the plot) in the collection region, then the plant material (leaves, branches and stem) was allocated in brown paper envelopes identified and submitted to oven drying with forced air circulation at $65{ }^{\circ} \mathrm{C}$, until constant weight. Subsequently, the material was weighed in a digital scale to obtain SDM.

For the physiological analyses of the seedlings, the relative levels of chlorophyll $a(\mathrm{Cla})$ and $b(\mathrm{Clb})$ were verified; and chlorophyll a fluorescence at 24 months after planting, in one representative plant per replicate. The evaluation of the relative chlorophyll content was performed using a chlorophyll meter (ClorofiLOGFalker), in expanded leaves of the upper third of the plant, measuring one leaf per plant (two readings per leaf) (Barbieri Junior et al., 2012). The determination of chlorophyll $a$ fluorescence was performed using a portable light-modulated fluorometer (JuniorPam Chlorophyll Fluorometer), in expanded leaves attached to the plant, on sunny days, between 08:00 and 10:30 in the morning. Leaves of the upper third of the plant were selected and wrapped in foil for 30 minutes to adapt to the dark. Then, fluorescence measurements were taken, obtaining the values of initial fluorescence $\left(\mathrm{F}_{\mathrm{o}}\right)$, maximum fluorescence $\left(\mathrm{F}_{\mathrm{m}}\right)$ and maximum quantum yield of photosystem II $\left(\mathrm{F}_{\mathrm{v}} /\right.$ $\left.\mathrm{F}_{\mathrm{m}}\right)$. The physiological attributes were not determined in seedlings of $P$. rigida due to the small size of their leaflets, making the contact between the devices and the leaf impossible.

\subsection{Statistical analysis}

The data were checked for the normality assumptions of the error distribution and homogeneity of variance, respectively, by the Shapiro-Wilk and Bartlett tests. Subsequently, the data were submitted to analysis of variance (ANOVA) and, when a difference between the treatments was found by the $\mathrm{F}$ test, the means were compared using the Student's $t$-test $(\mathrm{p}<0.05)$. The statistical software SISVAR (Ferreira, 2014) was used for these analyses.

\section{RESULTS}

The statistical analysis indicated that there was no interaction between the factors studied (container and mulching) for any variables investigated, therefore, they were analyzed and are presented in this section individually. The survival of the seedlings did not show any influence of the treatments used ( $p>0.05)$, for the three species (Table 3 ). There was a general survival mean of $72.5 \%$ for $C$. sylvestris seedlings, $85.0 \%$ for $H$. heptaphyllus and $80.0 \%$ for $P$. rigida. In relation to the increment in height and stem diameter (IncH and IncSD), there was a significant difference between the levels of the container factor in $C$. sylvestris seedlings, which presented higher values of IncH and IncSD when a plastic bag was used (53.15 $\mathrm{cm}$ and $13.58 \mathrm{~mm}$, respectively) (Table 3 ).

For H. heptaphyllus, the statistical analysis indicated a difference in both isolated factors 
Table 3 - Survival(s\%), increment in height (IncH) and increment in stem diameter (IncSD) of Casearia sylvestris, Handroanthus heptaphyllus and Parapiptadenia rigida seedlings at 24 months after field planting.

Tabela 3 - Sobrevivência (S\%), incremento em altura (IncH) e incremento em diâmetro do coleto (IncDC) de mudas de $\boldsymbol{C}$. sylvestris, $\boldsymbol{H}$. heptaphyllus e P. rigida aos 24 meses após o plantio a campo.

\begin{tabular}{|c|c|c|c|c|c|c|c|c|c|}
\hline Factors** & & sylvestris & & & heptaphy & & P. rigida & & \\
\hline Container & $\begin{array}{c}\mathrm{S} \\
\%\end{array}$ & $\begin{array}{l}\begin{array}{l}\text { IncH } \\
(\mathrm{cm})\end{array} \\
\end{array}$ & $\begin{array}{c}\text { IncSD } \\
(\mathrm{mm})\end{array}$ & $\begin{array}{c}\mathrm{S} \\
\% \\
\end{array}$ & $\begin{array}{l}\text { IncH } \\
(\mathrm{cm})\end{array}$ & $\begin{array}{c}\text { IncSD } \\
(\mathrm{mm})\end{array}$ & $\begin{array}{c}\mathrm{S} \\
\% \\
\end{array}$ & $\begin{array}{l}\text { IncH } \\
(\mathrm{cm})\end{array}$ & $\begin{array}{l}\begin{array}{l}\mathrm{IncSD} \\
(\mathrm{mm})\end{array} \\
\end{array}$ \\
\hline Plastic Bag & $71.7^{\mathrm{ns}}$ & $53.2 \mathrm{a}^{*}$ & $13.58 \mathrm{a}$ & $83,3^{\text {ns }}$ & $131.0 \mathrm{a}$ & $22.66 \mathrm{a}$ & $83.3^{\text {ns }}$ & $119.9^{\text {ns }}$ & $14.6^{\mathrm{ns}}$ \\
\hline Tube & 73.3 & $29.8 \mathrm{~b}$ & $8.40 \mathrm{~b}$ & 86,7 & $107.9 \mathrm{~b}$ & $16.49 \mathrm{~b}$ & 76.7 & 128.3 & 15.7 \\
\hline Mulching & $\begin{array}{l}\mathrm{S} \\
\%\end{array}$ & $\begin{array}{l}\mathrm{IncH} \\
(\mathrm{cm})\end{array}$ & $\begin{array}{c}\text { IncSD } \\
(\mathrm{mm})\end{array}$ & $\begin{array}{c}\mathrm{S} \\
\%\end{array}$ & $\begin{array}{l}\mathrm{IncH} \\
(\mathrm{cm})\end{array}$ & $\begin{array}{c}\text { IncSD } \\
(\mathrm{mm})\end{array}$ & $\begin{array}{c}\mathrm{S} \\
\%\end{array}$ & $\begin{array}{l}\mathrm{IncH} \\
(\mathrm{cm})\end{array}$ & $\begin{array}{r}\mathrm{IncSD} \\
(\mathrm{mm})\end{array}$ \\
\hline Presence & $68.7^{\mathrm{ns}}$ & $45.4^{\text {ns }}$ & $11.52 \mathrm{~ns}$ & $88.3^{\text {ns }}$ & $127.7 \mathrm{a}$ & $21.22 \mathrm{a}$ & $76.7^{\mathrm{ns}}$ & $109.6 \mathrm{~b}$ & $14.3^{\mathrm{ns}}$ \\
\hline Absence & 76.6 & 37.6 & 10.46 & 81.7 & $111.3 \mathrm{~b}$ & $17.94 \mathrm{~b}$ & 83.3 & $138.6 \mathrm{a}$ & 15.9 \\
\hline$\overline{C V 1(\%)}$ & 18.85 & 13.24 & 17.77 & 20.33 & 9.46 & 11.95 & 22.56 & 33.00 & 24.15 \\
\hline CV2 $(\%)$ & 32.72 & 23.73 & 15.66 & 18.60 & 12.40 & 7.42 & 20.02 & 13.84 & 16.02 \\
\hline
\end{tabular}

(container and mulching), and for the recipient, the seedlings from the plastic bag obtained higher $\mathrm{IncH}$ and IncSD (131.02 $\mathrm{cm}$ and $22.66 \mathrm{~mm}$ respectively) than those produced in polypropylene tubes $(107.98$ $\mathrm{cm}$ and $16.49 \mathrm{~mm}$, respectively). In relation to the mulching factor, the seedlings presented a higher increase in height and stem diameter when there was presence of mulch in their surroundings (127.69 $\mathrm{cm}$ and $21.22 \mathrm{~mm}$, respectively) (Table 3). It was also verified that, for the $P$. rigida seedlings, unlike the species previously mentioned, the containers tested did not show influence on the shoot increase. However, there was a significant difference between the mulching factor levels for the $\mathrm{IncH}$ variable, and a larger increase $(138.65 \mathrm{~cm})$ was observed in seedlings with no mulch coverage at planting.

Seedlings of $C$. sylvestris and $H$. heptaphyllus showed similar behavior regarding crown area (CA) and shoot dry mass (SDM), with significant difference between both factors tested, but without interaction. For both species, in relation to the recipient, the highest values of CA and SDM were found in seedlings transplanted to plastic bags, with averages of $0.219 \mathrm{~m}^{2}$ of CA and $90.97 \mathrm{~g}$ of SDM in C. sylvestris and 0.935 $\mathrm{m}^{2}$ of CA and $308.20 \mathrm{~g}$ of SDM in H. heptaphyllus (Table 4). In addition, there was a positive effect for the presence of mulch, with values higher than $0.197 \mathrm{~m}^{2}$ of CA and $80.10 \mathrm{~g}$ of SDM in C. sylvestris and 0.786 $\mathrm{m}^{2}$ of CA and $252.00 \mathrm{~g}$ of SDM in H. heptaphyllus. For $P$. rigida, there were only differences between the types of containers. The seedlings from plastic bags presented higher averages, both in CA $\left(1,971 \mathrm{~m}^{2}\right)$ and in $\operatorname{SDM}(581,10 \mathrm{~g})$, than those produced and kept in tubes (1.214 $\mathrm{m}^{2} \mathrm{CA}$ and $\left.305.80 \mathrm{~g} \mathrm{SDM}\right)$ (Table 4).

Regarding the physiological attributes, there was no significant difference between the treatments

Table 4 - Crown Area (CA) and shoot dry mass (SDM) of Casearia sylvestris, Handroanthus heptaphyllus and Parapiptadenia rigida seedlings at 24 months after field planting.

Tabela 4 - Área da copa (AC) e massa seca da parte aérea (MSPA) de mudas de C. sylvestris, H. heptaphyllus e P. rigida, aos 24 meses após o plantio a campo.

\begin{tabular}{|c|c|c|c|c|c|c|}
\hline \multirow{2}{*}{$\frac{\text { Factors** }}{\text { Container }}$} & \multicolumn{2}{|c|}{ C. sylvestris } & \multicolumn{2}{|c|}{ H. heptaphyllus } & \multicolumn{2}{|c|}{ P. rigida } \\
\hline & $\mathrm{CA}\left(\mathrm{m}^{2}\right)$ & SDM (g) & $\mathrm{CA}\left(\mathrm{m}^{2}\right)$ & SDM (g) & $\mathrm{CA}\left(\mathrm{m}^{2}\right)$ & SDM (g) \\
\hline Plastic Bag & $0.219 \mathrm{a}^{*}$ & $80.97 \mathrm{a}$ & $0.935 \mathrm{a}$ & $308.20 \mathrm{a}$ & $1.971 \mathrm{a}$ & $\overline{581.10 \mathrm{a}}$ \\
\hline Tube & $0.125 \mathrm{~b}$ & $55.60 \mathrm{~b}$ & $0.393 \mathrm{~b}$ & $118.20 \mathrm{~b}$ & $1.214 \mathrm{~b}$ & $305.80 \mathrm{~b}$ \\
\hline Mulching & $\mathrm{CA}\left(\mathrm{m}^{2}\right)$ & SDM (g) & $\mathrm{CA}\left(\mathrm{m}^{2}\right)$ & SDM (g) & $\mathrm{CA}\left(\mathrm{m}^{2}\right)$ & $\mathrm{SDM}(\mathrm{g})$ \\
\hline Presence & $0.197 \mathrm{a}$ & $80.10 \mathrm{a}$ & $0.786 \mathrm{a}$ & $252.00 \mathrm{a}$ & $1.545^{\mathrm{ns}}$ & $431.70^{\mathrm{ns}}$ \\
\hline Absence & $0.147 \mathrm{~b}$ & $56.47 \mathrm{~b}$ & $0.542 \mathrm{~b}$ & $174.40 \mathrm{~b}$ & 1.638 & 455.2 \\
\hline$\overline{C V 1(\%)}$ & 20.29 & 20.22 & 23.88 & 14.59 & 35.33 & $\overline{25.92}$ \\
\hline CV2 (\%) & 14.68 & 24.45 & 21.27 & 11.00 & 16.86 & 14.77 \\
\hline
\end{tabular}

*Means followed by different lowercase letters in the column differ from each other by the $\mathrm{t}$ test $(\mathrm{p}<0.05)$. **Factors were analyzed individually, ns - non-significant. CV1: Coefficient of variation of plot. CV2: Coefficient of variation of the subplot.

*Médias seguidas por letras minúscula diferentes na coluna diferem entre si pelo teste $t(p<0,05)$. ns - não-significativo. CV1: Coeficiente de variação da parcela. CV2: Coeficiente de variação da subparcela.

Revista Árvore 2021;45:e4520 
tested, for both $C$. sylvestris and H. heptaphyllus. In seedlings of $C$. sylvestris, the general averages of the attributes were: 29.59 and $8.54 \mathrm{FCI}$ of $\mathrm{Cl} a$ and $\mathrm{Cl} b$, respectively, 193.35 of $\mathrm{F}_{\mathrm{o}}, 408.6$ of $\mathrm{F}_{\mathrm{m}}$ and 0.485 of $\mathrm{F}_{\mathrm{v}} / \mathrm{F}_{\mathrm{m}}$. For seedlings of $H$. heptaphyllus the general averages were 24.30 and $5.95 \mathrm{FCI}$ of $\mathrm{Cl} a$ and $\mathrm{Cl} b$, respectively, 192.15 of $\mathrm{F}_{\mathrm{o}}, 496.25$ of $\mathrm{F}_{\mathrm{m}}$ and 0.606 of $\mathrm{F}_{\mathrm{v}} / \mathrm{F}_{\mathrm{m}}$.

Regarding the planting area, it should be noted that the weeds present in the area showed intense development in the first months after the planting of the seedlings.

\section{DISCUSSION}

Among the species studied, there was a lower survival rate for seedlings of $C$. sylvestris (72.5\%). Although it is considered a pioneer (Lorenzi, 2008), its high mortality shows less resistance of this species to tolerate the limiting factors (such as weed competition, compacted soil with a low content of organic matter, among others) that occurred in the planting area. This fact was corroborated by the small increase of the seedlings (Table 3 ), making them more susceptible to competition with weeds, with widespread occurrence in the area. This suggests the need for greater care in the management when planting $C$. sylvestris in altered areas, such as planting this species in areas where the first stages of vegetation can be found.

On the other hand, the survival rates of $H$. heptaphyllus $(85 \%)$ and $P$. rigida $(80 \%)$ showed greater adaptability to altered site conditions. The success of planting native trees for forest restoration depends on the knowledge about the behavior of the tree species used, in relation to survival and growth in the face of adverse conditions (Martinez-Garza et al., 2013). Schievenin et al. (2012) report that the survival rate of the seedlings allows to infer what maintenance is needed, as well as whether the species used and the cultural treatments are adequate for the conditions of the area. In the present study, survival analysis demonstrated the specificity of each species to tolerate adversities at the site of planting. In this case, we highlight that the area of the experiment was strongly impacted by anthropic action.

According to Silva et al. (2016), plantings with survival above $80 \%$, in the Atlantic Forest Biome, can be considered satisfactory and they also point out that mortality is an inherent characteristic of the place where planting place and their ability to adapt to field conditions. This condition was also verified by Morais Junior et. al (2020), who, when conducting a study with five native Atlantic Forest species, produced in different containers and, afterwards, planted in a degraded area, verified different behavior for each species. While some showed a higher survival rate when produced in larger containers, for others this factor was irrelevant.

Martinez-Garza et al. (2013), when evaluating the behavior of 24 tree species planted in a restoration area on abandoned pastures in Mexico, found that survival varied greatly between species (from 9 to $96 \%$ ), with the highest rates observed for pioneers.

The results found in this study, as well as in those cited above, reinforce the need to carefully choose the species to be used, through the analysis of their behavior in the field, choosing species and methods that present high survival, avoiding unnecessary expenses with replanting. In addition, it should be considered that the establishment period of the seedlings is a critical moment for the recovery, to be successful, and care with planting, such as irrigation and weed mowing, in the first months must be intensified, in order to favor survival (Campoe et al., 2014). This fact was evidenced in the present study, in which there was a need for constant monitoring during the first year, considering that the weeds present in the area showed intense development in the first months after the planting of the seedlings, which corresponded to a period with high temperatures and constant precipitation. In this phase, the seedlings were still being established, therefore, in addition to the silvicultural practices aiming to diminish the weed competition, a greater frequency in the control of leafcutter ants was also necessary.

Increases in height and stem diameter, CA and SDM of seedlings of $C$. sylvestris and $H$. heptaphyllus, in addition to the $\mathrm{CA}$ and SDM of $P$. rigida, were favored by the use of the plastic bags, possibly due to the higher volume of the substrate provided by such container. Field growth for seedlings of forest species produced in different recipient volumes has already been verified by other studies (Gasparin et al., 2017; Zavistanovicz et al., 2020), and in most of them, a larger volume is associated to the greater development of the seedlings in the field, as evidenced by Morais Junior et al. (2020).

Revista Árvore 2021;45:e4520 
This occurs because when the seedlings are produced in containers of small dimensions, they require a series of actions to favor their growth, due to the smaller volume of substrate in the container, less amount of available nutrients, as well as, less accumulation of water (Davide et al., 2015), while for larger containers, such as plastic bags, the opposite is evident. In addition, smaller container volumes, such as $180 \mathrm{~cm}^{3}$ tubes, may limit the growth of the root system of the seedlings (Abreu et al., 2015).

Thus, by controlling the amount of roots that the plant can produce, the volume of the recipient also determines the height of the shoot part (Ritchie et al., 2010), since the plants tend to present a balanced growth between the root and shoot part (Abreu et al., 2015).

It is suggested that the volume of the container used influences less the behavior of the seedlings when they are planted at suitable sites (Pinto et al., 2011). However, when the planting area presents limiting factors to survival and growth, as is the case in most of the altered areas, the authors emphasize that the volume of the container will be decisive for success in planting.

According to the species, it may occur that the type and volume of the container used do not significantly interfere with the growth in height and stem diameter of seedlings after planting, as verified in this study for $P$. rigida. Although the study by Ferraz and Engel (2011), shows that seedlings of this species presented higher growth when produced in containers of larger volume, in the nursery phase, this research did not consider their development in the post-planting, and sowing occurred directly in all containers, a fact that may have influenced the final result.

The behavior observed in the present study for $P$. rigida is characteristic of fast-growing species, generally included in the pioneer group and that present a greater rusticity and capacity to tolerate less favorable environments and environmental conditions (Nunes et al., 2015). Although in the nursery phase the container with higher volume favors the growth of the seedlings, there is a tendency for this growth difference to decrease gradually after planting in the field, as verified for seedlings of E. contortisiliquum (Abreu et al., 2015), which presented high growth rates, as well as $P$. rigida.
It should be noted, however, that the seedlings of $P$. rigida produced in plastic bags showed a better performance in CA and SDM, a fact that was possibly favored by the more developed root system, providing the expansion of the CA and, consequently, of the SDM. According to Ritchie et al. (2010), the growth of the seedlings in the shoot area is generally correlated with the number of leaves of the plant, being a good estimate of their photosynthetic capacity. The authors point out that, in planting sites with high vegetative competition, as in the present study, the ability to capture and process sunlight is decisive for plant survival and growth. Therefore, seedlings with more developed shoot areas have advantages over smaller seedlings that tend to be suppressed by competing vegetation (Ritchie et al., 2010).

In cases where the species has an adequate development when produced in different container volumes, as occurred for $P$. rigida, the choice of which to use should consider the final objective of planting (restoration, production, others) and the costs involved during production, considering that the use of larger containers, according to Ferraz and Engel (2011), implies an increase in implantation costs, because of the higher consumption of substrates, the need for more space in the nursery and the higher cost of transportation.

Besides the container influence observed, it was verified that the use of mulching favored the growth of plants of $C$. sylvestris and H. heptaphyllus. The beneficial effects of mulching on the planting of tree species were also evidenced by Dostalek et al. (2007), who verified that the growth of the seedlings was up to three times higher compared to those with no cover. The same authors point out that the species present different behaviors regarding the presence of mulching and that different materials must be tested to cover the soil in order to determine the one that best meets the needs of the area and the species used.

Different from the other species of this study, in seedlings of $P$. rigida the use of mulching proved to be unfavorable for the morphological attributes, mainly for IncH. This result may have been influenced by the pioneering characteristic of the species, which, even in view of the growth potential of the seedlings produced in a plastic bag, did not need to invest in

Revista Árvore 2021;45:e4520 
aerial growth to overcome the weed competition, which in turn had its growth inhibited by mulching.

Therefore, as with the container, the use of mulching should be considered for each species individually, considering the different responses obtained in each situation and their relevance. In plantings in altered areas, especially in those whose soil is exposed, the use of mulching should be analyzed regarding not only the benefit it provides to the growth of the seedlings, but also the capacity of physical protection that it offers, becoming a possible method for avoiding erosion.

Other soil covering techniques have been used in forest restoration plantations, aiming mainly at the control of weeds, such as the use of 'cardboards' mulch. Silva et al. (2018) found that the use of cardboard not only helped in the control of weeds, but also reduced the temperature at the soil surface, allowing for adequate development of seedlings in the field, because of the improvement in soil conditions.

Besides that, it is necessary to evaluate the availability of the materials to be used, opting for materials found close to the planting area, in order to make the process feasible economically.

In the present study, the physiological attributes were not altered by the treatments used for both $C$. sylvestris and $H$. heptaphyllus. This indicates that even the seedlings that obtained lower growth, were in similar physiological condition in the different treatments. Among the evaluated physiological attributes, the relationship between variable fluorescence and maximum fluorescence $\left(\mathrm{F}_{\mathrm{v}} / \mathrm{F}_{\mathrm{m}}\right)$, a measure of the intrinsic or maximum efficiency of photosystem II (PSII), stands out (Araújo and Deminicis, 2009).

The values of $\mathrm{F}_{\mathrm{v}} / \mathrm{F}_{\mathrm{m}}$ for both species were below the recommended (0.75-0.85) by Araújo and Deminicis (2009) suggesting that the plants were exposed to stress conditions, mainly $C$. sylvestris, due to the reduced value of $\mathrm{F}_{\mathrm{v}} / \mathrm{F}_{\mathrm{m}}(0.485)$.

This fact was probably due to the high weed competition present at the planting site, because when plants are exposed to restrictive environmental factors (weed competition, nutritional deficiency, water stress), it is common to observe falls in the value of this physiological attribute, being indicative of stress (Araújo and Deminicis, 2009).

\section{CONCLUSIONS}

The survival of C. sylvestris, H. heptaphyllus and P. rigida was not influenced by the treatments applied.

For the rapid growth of $C$. sylvestris, $H$. heptaphyllus and $P$. rigida in the altered area, seedlings produced in larger containers, such as $1.5 \mathrm{~L}$ polyethylene plastic bags, should be used.

For $C$. sylvestris and $H$. heptaphyllus, the use of mulching favors growth after planting, and it is appropriate to use it whenever it is available in the planting area.

\section{AUTHOR CONTRIBUTIONS}

T.C.Z: Conceptualization, Methodology, Formal analysis, Investigation. S.C.A: Methodology, Writing - review \& editing; M.M.A: Conceptualization, Methodology, Writing - review \& editing, Supervision.

Á.L.P.B., D.R.G. and F.M.B.: Methodology, review.

\section{ACKNOWLEDGEMENT}

To the Coordination for the Improvement of Higher Education Personnel (CAPES), for the granting of the Master's scholarship to the first author. To the Environmental Fund of the Caixa Econômica Federal (AC FSA CAIXA, N. 015,007/2012).

\section{REFERENCES}

Abreu AHM, Leles PSS, Melo LA, Ferreira DHAA, Monteiro FAS. Produção de mudas e crescimento inicial em campo de Enterolobium contortisiliquum produzidas em diferentes recipientes. Floresta. 2015;45(1):141-150. doi: 10.5380/rf.v45i1.28931.

Alvares CA, Stape JL, Sentelhas PC, Gonçalves JLM, Sparovek G. Köppen's climate 353 classification map for Brazil. Meteorologische Zeitschrift. 2013;2:1-18. doi:10.1127/09412948/2013/0507.

Araújo SA do C, Deminicis BB. Fotoinibição da fotossíntese. Revista Brasileira de Biociências. 2009;7(4):463-472.

\section{Revista Árvore 2021;45:e4520}


Barbieri Junior E, Rossiello ROP, Silva RVMM, Ribeiro CR, Morenz MJF. Um novo clorofilômetro para estimar os teores de clorofila em folhas do capim Tifton 85. Ciência Rural. 2012;42(12):22422245. doi: 10.1590/S0103-84782012005000109.

Brancalion PHS, Campoe OM, Teixeira JC, Noel C, Moreira GG, Van MJ, Stape JL, Guillemot J. Intensive silviculture enhances biomass accumulation and tree diversity recovery in tropical forest restoration. Ecological Applications. 2019;1: e01847. doi:https: 10.1002/eap.1847.

Brancalion PHS, Holl KD. Guidance for successful tree planting initiatives. Journal of Applied Ecology. 2020;57:2349-2361. doi: 10.1111/1365-2664.13725.

Campoe OC, Iannell C, Stape JL, Cook RL, Mendes JCT, Vivian R. Atlantic forest tree species responses to silvicultural practices in a degraded pasture restoration plantation: From leaf physiology to survival and initial growth. Forest Ecology and Management. 2014;313:233-242. doi: 10.1016/j. foreco.2013.11.016.

Chazdon RL. Beyond deforestation: restoring forests and ecosystem services on degraded lands. Science. 2008;320:1458-1460. doi: 10.1126/science.1155365.

Davide AC, Melo LA de, Teixeira LAF, Prado NJS, Fiorine RA, Carvalho RP de. Fatores que afetam a qualidade de mudas destinadas aos projetos de restauração de ecossistemas florestais. In: Davide AC, Botelho AS, editors. Fundamentos e métodos de ecossistemas florestais: 25 anos de experiência em matas ciliares. Editora UFLA; 2015. p. 181-274. ISBN: 9788581270456.

Dostalek J, Weber M, Matula S, Frantík T. Forest stand restoration in the agricultural landscape: The effect of different methods of planting establishment. Ecological engineering. 2007;29: 77-86. doi: 10.1016/j.ecoleng.2006.07.016.

Ferraz AV, Engel VL. Efeito do tamanho de tubetes na qualidade de mudas de jatobá (Hymenaea courbaril L. VAR. stilbocarpa (Hayne) Lee et Lang.), ipê-amarelo (Tabebuia chrysotricha (Mart. ex DC.) Sandl.) e guarucaia (Parapiptadenia rigida (Benth.) Brenan). Revista Árvore. 2011;35(3):413423. doi: 10.1590/S0100-67622011000300005.

Ferreira DF. Sisvar: a guide for its bootstrap procedures in multiple comparisons. Ciência e Agrotecnologia. 2014;38(2):179-182. doi: 10.1590/ S1413-70542014000200001.

Gasparin E, Araujo MM, Zavistanovicz TC, Aimi SC, Leon EB, Berghetti ALP. Supervivencia y crecimiento inicial de Parapiptadenia rigida en campo. Floresta. 2017;47(4):536-542. doi: 10.5380/ rf.v47i4.54234.

Gonçalves JLM, Santarelli EG, Moraes Neto SP, Manara MP. Produção de mudas de espécies nativas: substrato, nutrição, sombreamento e fertilização. In: Gonçalves JLM, Benedetti V. editors. Nutrição e fertilização florestal. Editora IPEF; 2005. p. 309-350. ISBN: 9788590135814.

Lima Filho P, Leles PSS, Abreu AHM de, Silva EV da, Fonseca AC da. Produção de mudas de Ceiba speciosa em diferentes volumes de tubetes utilizando o biossólido como substrato. Ciência Florestal. 2019;29(1):27-39. doi: 10.5902/1980509819340.

Lorenzi H. Árvores brasileiras: manual de identificação e cultivo de plantas arbóreas nativas do Brasil. 5 ed. Instituto Plantarum; 2008.

Martinez-Garza C, Bongers F, Poorter L. Are functional traits good predictors of species performance in restoration plantings in tropical abandoned pastures? Forest Ecology and Management. 2013;303:35-45. doi: 10.1016/j. foreco.2013.03.046.

Morais Junior VTM de, Jacovine LAG, Oliveira K, Albuquerque TP, Faustino IS, Silva LB, et al. Performance of five native atlantic forest species planted in containers of different size for restoring degraded areas in Minas Gerais. Forests. 2020;11(937):1-9. doi:10.3390/f11090937.

Nunes YRF, Fagundes NCA, Veloso MDM, Gonzaga APD, Domingues EBS, Almeida HS, et al. Sobrevivência e crescimento de sete espécies arbóreas nativas em uma área degradada de floresta estacional decidual, norte de Minas Gerais. Revista Árvore. 2015;39(5):801-810. doi: 10.1590/010067622015000500003.

Paula RC de, Silveira RML, Rocha MM, Izzo TJ. The restoration of termite diversity in different reforestated forests. Agroforest Systems. 2016;90:395-404. doi: 10.1007/s10457-015-9862-2.

Revista Árvore 2021;45:e4520 
Pinto JR, Marshall JD, Dumroese RK, Davis AS, Cobos DR. Establishment and growth of container seedlings for reforestation: A function of stocktype and edaphic conditions. Forest Ecology and Management. 2011;261:1876-1884. doi: 10.1016/j. foreco.2011.02.010.

Ritchie GA, Landis TD, Dumroese RK, Haase DL. Assessing plant quality. In: Landis TD, Dumroese RK, Haase DL. Seedling processing, storage, and outplanting. v.7. Washington: Department of Agriculture Forest Service; 2010.

Schievenin DF, Tonello KC, Valente ROS, Faria LC, Thiersch CR. Monitoramento de indicadores de uma área de restauração florestal em SorocabaSP. Revista Científica Eletrônica de Engenharia Florestal. 2012;19(1):95-108.
Silva KA, Martins SV, Miranda Neto A, Demolinari RA, Lopes AT. Restauração florestal de uma mina de bauxita: avaliação do desenvolvimento das espécies arbóreas plantadas. Floresta e Ambiente. 2016;23(3):309-319. doi: 10.1590/21798087.142515 .

Silva FF, Resende AS de, Santos TA dos, Chaer GM. Use of cardboard disks for crowning seedlings in reforestation. Floresta e Ambiente. 2018;25(3):1-7. doi: 10.1590/2179-8087.026116.

Zavistanovicz TC, Gasparin E, Araujo MM, Cargnelutti Filho A, Aimi SC, Foltz DRB, Dorneles DU. Nursery and field growths of Enterolobium contortisiliquum seedlings produced in different containers and fertilizer doses. Revista Brasileira de Ciências Agrárias. 2020; 15(3): 1-8. doi: 10.5039/ agraria.v15i3a7507. 